\title{
The Effects Of Antimicrobial And Physical Properties Of Denture Soft Reline Material
}

\author{
Yu-Ri Choi ${ }^{1}$, Min-Kyung Kang ${ }^{2 *}$ \\ ${ }^{1}$ Department of Dental Hygiene, Hallym Polytechnic University, 48 Janghakgil, Dong-Myeon, Chuncheon-si, - \\ Gangwon-do, 24210, Republic of Korea, \\ 2* Department of Dental Hygiene, Hanseo University, 46 Hanseo 1-ro, Haemi-myun, Seosan-si, \\ Chungcheongnam-do, 31963, Republic of Korea
}

Article History:Received:11 February 2021; Accepted: 27 March 2021; Published online: 5 April 2021

\begin{abstract}
Candida albicans(C. albicans) is one of the bacteria that resides in the oral cavity, and the ones living in medical and commercial denture resins, commonly cause diseases. Therefore, this study was conducted to confirm the antibacterial activity of $C$. albicans using a denture base resin containing peony extract with antibacterial properties.

For the antibacterial effect, optical density and confocal laser microscopy were used. Contact angle measurements and color change measurements were performed to confirm the physical change of the material added with the antibacterial agent to the denture reline resin.

As a result of the antibacterial test, the experimental group exhibited antibacterial activity against $C$. albicans. Compared to the optical density results, the results of the experimental group showed a significant difference. As a result of Fluorescent images showing (confocal laser microscope), the control group showed a lot of live bacteria, no bacteria appeared in the experimental group. All group did not show any physical changes. As a result of the contact angle measurement, the surface of the experimental group was changed to hydrophilic. In addition, there was no change in the color of the denture reline resin containing peony extract. In conclusion, it was confirmed that the peony extract contained antibacterial activity of the denture resin, and further studies should be conducted on various bacteria for denture base resin disinfection.
\end{abstract}

Keywords: Antibacterial effects; Candida albicans; Natural extract; Peony extract; Soft denture reline resin.

\section{INTRODUCTION}

Several bacteria, which cause many diseases in the oral cavity, are present in denture basin resins (Kim D V et $a l ., 2107)$. This study therefore aims to produce a denture base resin containing a peony extract that is known to have antibacterial activity. The goal is to examine the effectiveness of peony extract in soft denture resin.

Denture-induced stomatitis is primarily caused by the opportunistic fungal pathogen C. albicans; however, more Candida species are being implicated in pathogenesis. As peony extract has previously been used as an inhibitor against Streptococcus mutans and C. albicans (Krzyściak W et al., 2017; Zhang Y et al., 2017], we placed it in the denture resin to study the possibilities of denture-induced stomatitis, In addition, previous researchers investigated the antibacterial effectiveness of peony extract for studying its use as an inhibitor (Bansal V et al., 2020).

The lower residual alveolar that supports dentures is gradually absorbed as the masticatory force is applied, and the fitness for denture base and tissue is reduced.

The inability to receive such proper tissue support or suffering from residual alveolar injury owing to the uneven distribution of chewing power, it will also lead to patient discomfort, food insertion, and decrease in holding power (BinMahfooz A M et al., 2018).

A denture repair resin is used to restore the fitness between the denture base and the tissue. The denture repair resin should have physical properties similar to those of the denture base resin and must have good denture and bonding strength. In addition, due to the nature of the patient suffering from denture problems, the soft tissue inside the gingiva tends to be damaged (Stipho H D et al., 2001, Gundogdu M et al., 2015)

Moreover, we studied the effect of disinfectants on the stability of denture base acrylic resins, and found that they affected their color stability (May KB et al., 1992).

Therefore, in this study, the peony extract was prepared by including the denture tissue regulator, and the antibacterial activity, color change and contact angle were analyzed.

\section{MATERIALS \& METHODS}

\section{Extraction}

Peony extract was extracted using $70 \%$ methanol solution at room temperature for $48 \mathrm{~h}$. The solution was filtered, and thereafter, concentrated by evaporation in a vacuum evaporator. The concentrated extract was prepared in powdered form using a freeze dryer.

We used Coe-Comfort (GC, Japan) as the soft denture-reline resin material. The preparation of the specimen containing the peony extract involved the addition of extracted peony powder of various concentrations $(200 \mu \mathrm{g}$ / $\mathrm{mL}, 400 \mu \mathrm{g} / \mathrm{mL}$, and $600 \mu \mathrm{g} / \mathrm{mL}$ ) to the monomer solution. The monomer and the powder were then mixed

*Corresponding author: Min-Kyung Kang

Department of Dental Hygiene, Hanseo University, 46 Hanseo 1-ro, Haemi-myun, Seosan-si, Chungcheongnam-do, 31963, Republic of Korea

Email : kmk0709@hanseo.ac.kr 
according to the manufacturer's instructions. Thereafter, the mixture was poured into a mold (with a thickness of $1.0 \pm 0.1$ and diameter of $10.0 \pm 0.1 \mathrm{~mm}$ ) and kept aside for the set time.

\section{Antimicrobial test}

C. albicans (ATCC 10231) were incubated in a yeast and mold medium for $24 \mathrm{~h}$. The samples were then extracted into a 600-uL PBS (Gibco, Life Technologies, Roskilde, Denmark) and incubated for $24 \mathrm{~h}$. The bacterial culture fluid was diluted to obtain an OD600 value. After mixing the solution and bacterial culture in the ratio $1: 1$, the mixture was incubated at $37^{\circ} \mathrm{C}$ for $48 \mathrm{~h}$. The inhibitory effects of the extract were measured based on the optical density (OD) values in each well using an ELISA reader at $600 \mathrm{~nm}$.

C. albicans $\left(1 \times 10^{5} \mathrm{CFU} / \mathrm{mL}\right)$ were incubated on the specimen for $24 \mathrm{~h}$, and thereafter, stained using a bacterial viability kit, according to the manufacturer's protocols to confirm the viability of $C$. albicans. The stained $C$. albicans was observed under confocal laser microscopy (LSM700, Carl Zeiss, USA). Live C. albicans produced green fluorescence whereas dead C. albicans produced red fluorescence.

\section{Contact angle}

The contact angle was measured to check whether the hydrophilicity of the specimen with the extract had changed. The experimental group and the control group were dropped by $5 \mu \mathrm{L}$ of the distilled water using a contact angle measuring device (Phoenix 300, SEO, Korea), and the contact angle was measured immediately.

\section{Color change measurement}

To confirm the change in the color change among the three groups of both the experimental and control groups, color measurements were performed with a spectrophotometer (CM-3500d; Minolta, Kyoto, Japan). The standard white plate was set as the standard for measuring the color saturation, and the $\mathrm{L}^{*}, \mathrm{a}^{*}$, and $\mathrm{b}^{*}$ values of each specimen were obtained, and thereafter the $\Delta \mathrm{E}^{*}$ value (color change value) was calculated. The $\mathrm{L}^{*}$ value represents the brightness of the specimen, and the $a^{*}$ value represents the degree of green (negative $a^{*}$ ) or red (positive $\mathrm{a}^{*}$ ) fluorescence. The $\mathrm{b}^{*}$ value represents the degree of blue (negative $\mathrm{b}^{*}$ ) and yellow (positive $\mathrm{b}^{*}$ ) fluorescence. The formula for calculating $\triangle \mathrm{E}^{*}$ is as follows: measurements of each of the three specimens were obtained.

\section{RESULTS AND DISCUSSION}

Antimicrobial activity was evaluated based on the OD value (Figure 1). We observed a significant reduction in the OD value for specimens containing the peony extract. The control group $(0 \mu \mathrm{g} / \mathrm{mL})$ displayed lower antimicrobial activity when compared to the specimens containing the peony extract of concentrations 400 $\mu \mathrm{g} / \mathrm{mL}$ and $600 \mu \mathrm{g} / \mathrm{mL}(p<0.05)$. The specimen containing $600 \mu \mathrm{g} / \mathrm{mL}$ of peony extract exhibited the highest antimicrobial activity against $C$. albicans.

Figure 1 depicts the images of live and dead $C$. albicans. A distinctive difference could be observed between the control $(0 \mu \mathrm{g} / \mathrm{mL})$ and test groups $(200 \mu \mathrm{g} / \mathrm{mL}, 400 \mu \mathrm{g} / \mathrm{mL}$, and $600 \mu \mathrm{g} / \mathrm{mL})$. The number of viable C. albicans from the green fluorescent stain batch was considerably greater in the control group than in the test group. The number of dead $C$. albicans with a red fluorescent stain increased with increase in the concentration of peony extract (Figure 2). The contact angle of the experimental group was reduced compared to that of the control group. The experimental group was confirmed to have changed to hydrophilicity with decrease in the contact angle (Figure 3).

As a result of the color change, when the control group was used as the reference value, the color change of the experimental group was small. Table 1 lists the result of the color change values and they do not show any significant difference.

The tissue modulators exhibited changes in properties owing to the degeneration of the material itself due to the loss of ethanol, plasticizer, etc., depending on the course of use or the time of action, even if applied intraorally for a relatively shorter time period (within 7 days) (Lin J J et al., 1999).

In addition, biofilm formation can be realized owing to the weakening of the physical properties of the material surface and can serve as a storage for bacteria in the case of poor denture management or systemic disease. As a result, dendritic stomatitis can be related to Candia species, pharyngeal infection caused by Staphylococcus aureus, and upper respiratory tract infection (Shen C et al., 1989)

It is essential to prevent bacterial colonies through proper hygiene management of tissue control materials; however, mechanical, and chemical cleaning can change the physical properties of materials.

Most people who wear dentures are elderly, and therefore, physical immunity and oral hygiene management ability are relatively low; moreover, patients with limited mobility have problems such as drug overlap, overdose resistance, and increased treatment costs.

Peony extract is a natural extract that is widely known for its antibacterial activity. According to previous studies, peony extracts have weak antibacterial and toxic properties (Li XL et al., 2018; Krzyściak W et al., 2017). Therefore, we intended to produce a tissue control agent containing a peony extract by applying tissue 
control to the peony extract. In this study, tissue modulators were divided into 200, 400, and 600 groups, and experiments were conducted to confirm their antibacterial and physical changes. Absorbance was measured after culturing the bacteria to confirm the antibacterial activity of the group to which the tissue regulator was added. As a result, the experimental group showed a difference in the absorbance level due to the high degree of bacterial killing compared to the control group. In addition, antibacterial was measured with a confocal laser microscope to confirm the presence of bacteria. It was green(live bacteria) when the bacteria were alive and red when they were killed. The control group was found to have a lot of green color due to the high activity of the bacteria. Compared to the control group, the experimental group had few green-colored bacteria, and the result was mixed with red. Therefore, it was confirmed that the tissue control agent with the peony extract exhibited antibacterial activity. Because tissue modulators should not exhibit physical changes even if they have excellent antibacterial properties, important contact angles and color change among the physical properties applied to the dentures were confirmed. As a result of measuring the contact angle, it was confirmed that the experimental group was changed to hydrophilic compared to the control group. In the experimental group, the components of the peony extract showed hydrophilicity when combined with the tissue regulator, and this indicated a good result because they must always appear as hydrophilic due to the nature of dentures that are wet in the oral cavity. In addition, no color difference was indicated when a tissue control agent was added to the experimental group compared to the original tissue control agent. Tissue modifiers were added to dentures in the oral cavity to prevent any color change. Therefore, it was confirmed that the result which indicated no color change of the tissue control agent had a good effect on the denture production and application. The purpose of this study was to confirm the antibacterial activity of the peony extract among other natural extracts exhibiting antibacterial activity by adding it to a denture base resin. Compared to the control group, the experimental group showed excellent antibacterial activity and did not exhibit any physical change. Therefore, further studies should be conducted on the peony extract and the tissue regulator actually chemically bind, or when added to other products, exhibit the same results.

\section{CONCLUSION}

In this study, a tissue conditioner (Coe-Comfort) containing peony extract showed antibacterial effectiveness against $C$. albicans. In addition, dentures containing peony extract did not exhibit any significant difference during physical evaluation when compared to the control group. In conclusion, the antibacterial activity of denture cleaners, including peony extract, was confirmed.

\section{Funding Support}

This study was supported by the National Research Foundation of Korea (NRF) grant funded by the Korean government (MSIT) (No. 2017R1C1B5076310).

\section{Conflict of Interest}

The authors declare that they have no conflict of interest.

\section{ACKNOWLEDGMENT}

This study was supported by the National Research Foundation of Korea (NRF) grant funded by the Korean government (MSIT) (No. 2017R1C1B5076310).

\section{REFERENCES}

1. Bansal.V, Gupta. M, Bhaduri. T, Shaikh, S. A, Sayed. F. R, Bansal, V. Agrawal A, 2019. Assessment of antimicrobial effectiveness of neem and clove extract against Streptococcus mutans and Candida albicans: An in vitro study. Nigerian Medical Journal, 60(6), 285-289.

2. BinMahfooz, A. M, Qutub. O. A, 2018. Effect of surface treatments and adhesive materials on the shear bond strength of artificial denture teeth to denture base resins. The Journal of Contemporary Dental Practice, 19(6), 631-636.

3. Gundogdu. M, Yanikoglu. N, Bayindir. F, Ciftci. H, 2015. Effect of repair resin type and surface treatment on the repair strength of polyamide denture base resin. Dental Materials Journal, 34(4), 485489.

4. Kim. D, Sengupta A, Niepa. T. H. R, Lee. B. H, Weljie. A, Freitas-Blanco. V. S, Murata. R. M, Stebe. K. J, Lee. D, Koo. H, 2017. Candida albicans stimulates Streptococcus mutans microcolony development via cross-kingdom biofilm-derived metabolites. Sci Rep, Jan 30(7), 41332.

5. Krzyściak. W, Kościelniak, D, Papież, M., Vyhouskaya. P, Zagórska-Świeży. K, Kołodziej. I, Bystrowska. B, \& Jurczak. A, 2017. Effect of a Lactobacillus salivarius probiotic on a double-species Streptococcus mutans and Candida albicans caries biofilm. Nutrients, 9(11), 1242.

6. Li. X. L, Thakur, K, Zhang. Y. Y, 2018. Effects of different chemical modifications on the antibacterial activities of polysaccharides sequentially extracted from peony seed dreg. International Journal of 
Biological Macromolecules, 116, 664-675.

7. J. J. Lin, S.M. Carmeron, D.A. Runyan, D.W. Craft, 1999. Disinfection of denture base acrylic resin. Journal of Prosthetic Dentistry, Feb, 81(2), 202-6

8. May. K. B, Razzoog. M. E, Korean III A. Robinson E, 1992. Denture base resins: Comparison study of color stability. Journal of Prosthetic Dentistry, Jul, 68(1), 78-82.

9. Shen. C, Javid. N. S, Colaizzi, F. A, 1989. The effect of glutaraldehyde base disinfectants on denture base resins. Journal Prosthetic Dentistry, 61(5), 583-589.

10. Stipho. H. D, Talic. Y. F, 2001. Repair of denture base resins with visible light-polymerized reline material: effect on tensile and shear bond strengths. Journal Prosthetic Dentistry, 86(2), 143-148.

11. Zhang. Y, Li. X, Xu. X, Yang. N, 2019. Mechanisms of Paeonia lactiflora in treatment of ulcerative colitis: A network pharmacological study. Medical Science Monitor, 25, 7574-7580.

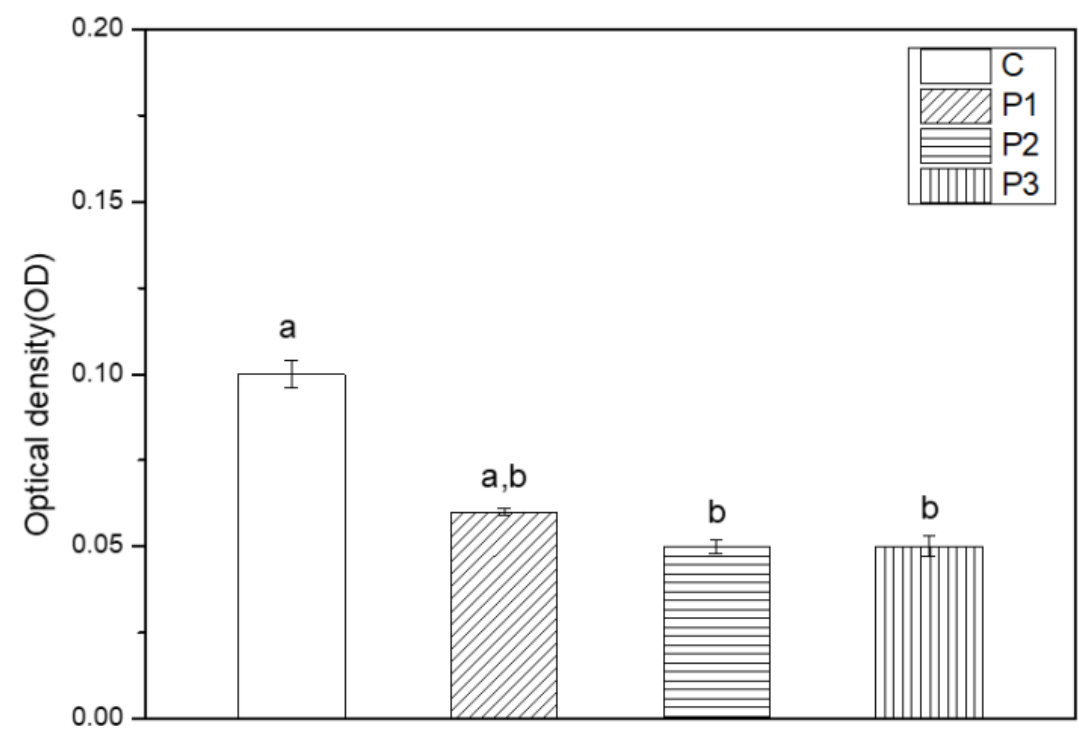

Figure 1: Antimicrobial activity of soft denture-reline resins containing peony extract $\mathrm{C}: 0 \mu \mathrm{g} / \mathrm{mL}, \mathrm{P1}$ : $200 \mu \mathrm{g} / \mathrm{mL}$, P2: $400 \mu \mathrm{g} / \mathrm{mL}$, and P3: $600 \mu \mathrm{g} / \mathrm{mL}$

a b denote significant differences by one-way ANOVA

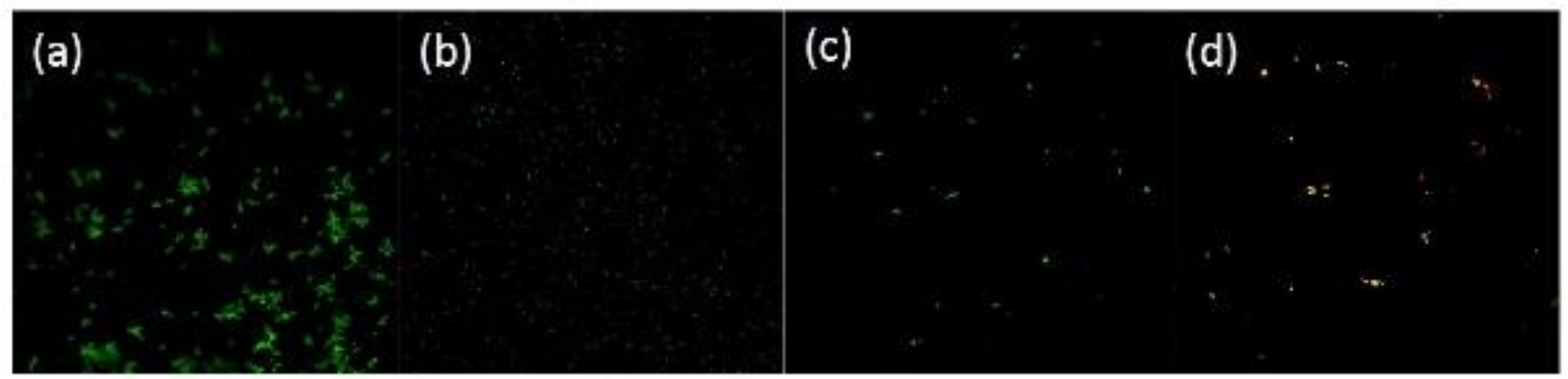

Figure 2: Fluorescent images showing the live (green) and dead (red) stained C. albicans following the concentration of peony extract (a) $0 \mu \mathrm{g} / \mathrm{mL}$, (b) $200 \mu \mathrm{g} / \mathrm{mL}$, (c) $400 \mu \mathrm{g} / \mathrm{mL}$, and (d) $600 \mu \mathrm{g} / \mathrm{mL}$ 


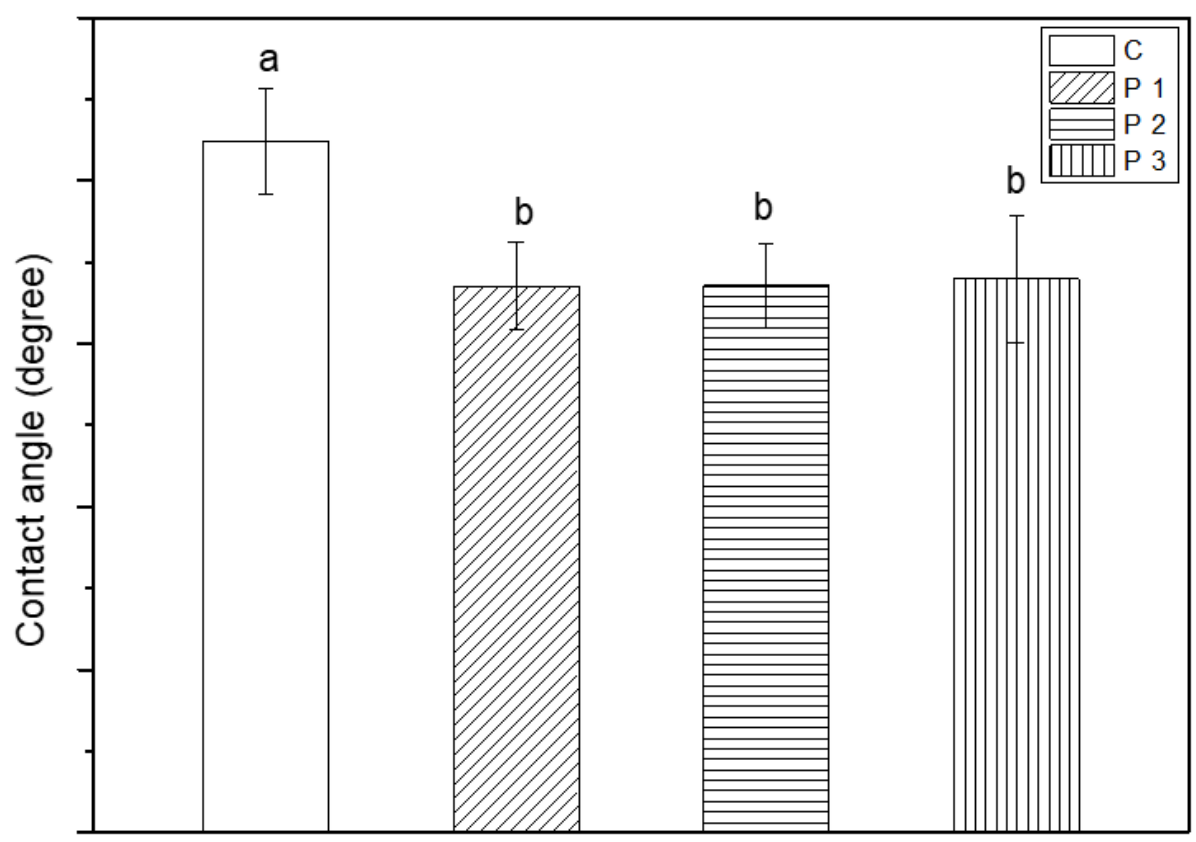

Figure 3: Contact angle measurement result C: $0 \mu \mathrm{g} / \mathrm{mL}, \mathrm{P1}: 200 \mu \mathrm{g} / \mathrm{mL}, \mathrm{P} 2: 400 \mu \mathrm{g} / \mathrm{mL}$, and P3: $600 \mu \mathrm{g}$ $/ \mathrm{mL}$ a b denote significant differences by one-way ANOVA

Table 1: Result of the color change

\begin{tabular}{ll}
\hline Group & $\triangle \mathrm{E}^{*}($ Mean $\pm \mathrm{SD})$ \\
\hline $200 \mu \mathrm{g} / \mathrm{mL}$ & $0.71 \pm 0.25$ \\
$400 \mu \mathrm{g} / \mathrm{mL}$ & $0.85 \pm 0.25$ \\
$600 \mu \mathrm{g} / \mathrm{mL}$ & $0.81 \pm 0.28$ \\
\hline
\end{tabular}

